Оригинални научни рад

Réka M. Pusztahelyi, Ph.D., Associate Professor

University of Miskolc

Faculty of Law

reka.pusztahelyi@gmail.com

\title{
REFLECTIONS ON CIVIL LIABILITY FOR DAMAGES CAUSED BY UNMANNED AIRCRAFTS ${ }^{1}$
}

Abstract: As the competence of the EU has been extended to cover the regulation of all drones involved in international air navigation regardless of their maximum take-off masses, and in accordance with the Single European Sky concept, a new Regulation (EU) 2018/1139 of the European Parliament and Council (Regulation) came into force in August 2018 regarding common rules in the field of civil aviation that also addresses the main questions relating to the utilisation of unmanned aircrafts, i.e. drones. While the Regulation and the implementative acts were elaborated, and comprehensive regulation at the EU level is becoming complete, the civil liability issues related to drone usage seem to remain on the national level, with the exception of the Product Liability Directive, provided that the cause of the drone accident was the defect of the product.

In this essay, the Hungarian strict liability statute, the rule of liability for highly dangerous activity, will be examined, especially from the viewpoint of the dangerousness of the activity, in order to assess how it can be applied to drone utilisation in the future.

Keywords: unmanned aircraft, EU regulation, drone categorisation, liability for highly dangerous activity, product liability.

${ }^{1}$ This research was supported by the project nr. EFOP-3.6.2-16-2017-00007, titled Aspects on the development of intelligent, sustainable and inclusive society: social, technological, innovation networks in employment and digital economy. The project has been supported by the European Union, co-financed by the European Social Fund and the budget of Hungary. 


\section{INTRODUCTION}

As the competence of the EU has been extended to cover the regulation of all drones ${ }^{2}$ involved in international air navigation ${ }^{3}$ regardless of their maximum take-off masses (MTOMs), and in accordance with the concept of Single European $\mathrm{Sky}^{4}$, a new Regulation (EU) No. 2018/1139 of the European Parliament and Council came into force in August 2018 (hereinafter: Regulation). It also addresses the main questions relating to the utilisation of unmanned aircrafts 5 . According to the principle of proportionality, this Regulation states that "for some types of unmanned aircraft, the application of the provisions of this Regulation related to registration, certification, identification, oversight and enforcement, as well as of the provisions regarding the Agency is not necessary in order to reach adequate levels of safety. Market surveillance mechanisms provided by Union product harmonisation legislation should be made applicable to those cases." In the field of aviation, implementing and delegated acts should come into force to cover the special issues relating to drones flying within EU airspace.

Relating to the open category in which many drones are sold as a consumer good for non-commercial use, the EU legislation exploits the fact that drones are a special kind of product in the EU market while also being aircrafts. For the sake

2 Classically 'drone' means a remotelly piloted arcraft systems (RPAS) propelled by multi rotors (multi rotors helicopters, i.e. multicopters). They are also called as unmanned aerial vehicle (UAV) or unmanned aircraft system (UAS). Hereby the drone, the unmanned aircraft or the unmanned aircraft system terms are used for the same meaning, for the sake of simplicity, paralelly with the Regulation definition of unmanned aircraft. The scope of the EU regulation covers all types of unmanned aircrafts (for recreational or for business use, but for only in civil aviation); such as remotelly piloted, autonomous or optionally piloted UAs, with the exception of so-called tethered aircrafts.

${ }^{3}$ Commission's Communication EU about "A new era for aviation - Opening the aviation market to the civil use of remotely piloted aircraft systems in a safe and sustainable manner" (No. $\operatorname{COM}(2014) 207)$; See: Chicago Convention on international civil aviation of year 1944. The Chicago Convention deals with unmanned aircrafts and lays drown the general priority rule in favor of manned aircrafts in its Article 8. See also: Riga Declaration on Remotely Piloted Air Systems: Framing the future of aviation, 6 March 2015, and the Resolution of the European Parliament on the safe use of remotely piloted aircraft systems (RPAS), commonly known as UAVs, in the field of civil aviation No. 2014/2243(INI), published: 20 October 2015.

${ }^{4}$ It was an initiative of the European Commission which provides a complex legislative framework for using EU airspace.

${ }^{5}$ The European Aviation Safety Agency (EASA) has got a key role in preparing and proposing new measures. Therefore, the EASA Opinion No. 01/2018, published on February 2018, entitled "Introduction of a regulatory framework for the operation of unmanned aircraft systems in the 'open' and 'specific' categories" was a significant step towards the regulation of drones as aircraft vehicles within the framework of the Single European Sky airspace concept. The main features of this regulatory proposal to the Commission were the risk-based approach, the principle of proportionality, and flexibility.

${ }^{6}$ Point 30, Preamble of Regulation (EU) No. 2018/1139. 
of mass production of drones, the EU legislation strives towards as simple a way of regulation as possible, with special regard to administrative rules concerning drone utilisation such as conformity for aeronautical usage, their identification and the administrative requirements for the devices. The existing method and, what is more, the existing rules of EU regulation of product safety, seem to be an appropriate way of setting the legal framework for drones in the category of lesser risk.

The first level of the proportionate regulation of drone utilisation is the set of these obligations for manufacturers. As the drones become safer and comply with the criteria of airworthiness, the risk of damage emerging from defects of the device could diminish.

For this reason, it is not the operators but the manufacturers who should perform a conformity assessment process on the drone prior to placing it on the market and affix a special CE marking on the product that indicates in the broad sense that the product is comply even with the requirements for aeronautical usage.

But the factor of human failure remains, therefore it is necessary to also touch upon the civil law liability questions, especially in light of a Communication with the title "Artificial Intelligence for Europe" that was released in spring $2018^{7}$ and its accompanying document "Liability for emerging digital technologies"8 that emphasised the great necessity to revise civil law liability regulations on an EU-wide level.

\section{REGULATIVE INTENTIONS AT BOTH THE NATIONAL AND EUROPEAN LEVELS}

It is obvious that harmonised EU regulation is unavoidable taking into account the geographical conditions of Europe, but the relatively slow legislative process of the EU and the great need for regulation ${ }^{9}$ led more Member States to establish national regulations (mainly addressing administrative questions such as licensing or limitation of use) for the purpose of public policy and the security and safety of individuals. ${ }^{10}$ Indeed, national regulations came into force beyond

\footnotetext{
${ }^{7}$ Communication from the Commission to the European Parliament, the European Council, the Council, the European Economic and Social Committee and the Committee of the Regions: "Artificial Intelligence for Europe" COM(2018) 237 final.

${ }^{8}$ Commission Staff Working Document SWD(2018) 137 final.

${ }^{9}$ In the light of the sales data and the crashes reported in the media from time to time.

${ }^{10}$ Kenneth Kuhn, Small Unmanned Aerial System Certification and Traffic Management Systems, RAND corporation, online, 2017 (https://www.rand.org/content/dam/rand/pubs/perspectives/PE200/PE269/RAND_PE269.pdf, 12 December 2018.). See: Italian regulation on remotelly piloted aerial vehicles (of year 2015) (https://www.enac.gov.it/ContentManagement/information/ N1068541283/Regulation_RPAS_Issue_2_Rev_3_eng.pdf, 15 January 2019) ; or: German regulation on operation of unmanned aerial vehicles (of 2017) (https://www.bmvi.de/SharedDocs/DE/
} 
Europe $^{11}$ with the same intention for general and comprehensive regulation. In Hungary, the Civil Aviation Act No. 97 of 1995 was amended according to the aforementioned EASA Opinion and the EU regulation (No. 2018/1139), but the implementing ministerial or governmental regulations are still missing due to waiting for the next step of EU implementing legislation.

The issues to be regulated in the national regulations were the following: drone categorisation, registration, authorisation for license, the subjective (operator) and objective (device) general criteria of operation, the actual conditions and limits of use. ${ }^{12}$ As far as civil law is concerned, all the rules for licensing and authorisation and operating standards belong to public law, and any unlawful or non-compliant conduct governed by these new regulations and measures explicitly triggers only public law sanctions (penalty or fine). These new regulations address civil law liability questions only indirectly.

On $4^{\text {th }}$ July 2018, the European Parliament and Council adopted the aforementioned EU regulation No. 2018/1139 which amends the common rules and regulations existing in the field of civil aviation. Th Preambulum states that "(s)ince unmanned aircraft also operate within the airspace alongside manned aircraft, this Regulation should cover unmanned aircraft, regardless of their operating mass." ${ }^{33}$ It also affirms that a risk-based approach and principle of proportionality will be observed throughout implementation, as the implementing acts (the implementing regulation ${ }^{14}$ and the delegated regulation of the Commission ${ }^{15}$ ) reflect them, as well.

It is an important detail that the regulative intention covers all types of UAVs regardless of their operating mass. ${ }^{16}$ It means that the Single European Sky airspace

Anlage/LF/verordnung-zur-regelung-des-betriebs-von-unbemannten-fluggeraeten.pdf, 15 January 2019). See: Guido Noto La Diega: Machine Rules. Of Drones, Robots, and the Info-Capitalist Society. The Italian Law Journal 2/2016, 367-404.

${ }^{11}$ Among studies with a comparative perspective see: Therese Jones, International Commercial Drone Regulation and Drone Delivery Services, RAND Publications https://www.rand. org/pubs/research_reports/RR1718z3.html; (12 December 2017) Adem Ilker, Regulating Commercial Drones: Bridging the Gap between American and Europe Drone Regulations, The Journal of International Business \& Law 15/2016, 313-335. ; The Law Library of Congress, Global Legal Research Center, Regulation of Drones. Australia $\bullet$ Canada $\bullet$ China $\bullet$ France $\bullet$ Germany $\bullet$ Israel Japan $\bullet$ New Zealand $\bullet$ Poland $\bullet$ South Africa $\bullet$ Sweden $\bullet$ Ukraine $\bullet$ United Kingdom $\bullet$ European Union (April 2016).

12 Veronika Szikora; Gabor Szilagyi, New Dangerous Practice on the Horizon: Legal Aspects of Drone Usage, 51 Zbornik Radova Pravnog Fakulteta, Novi Sad, 2/2017 499-519.

${ }^{13}$ Point 26 Preamble, Regulation (EU) No. .2018/1139. The registry will be kept by national aviation authorities, but the communication between national registers will be essentials. Therefore, in our opinion, the first, i.e. the lowest level degree of the flexible regulation system is the duty of registration of UAVs.

${ }^{14}$ Draft for implementing regulation of the Commission ref.No. Ares(2018)5119803.

${ }^{15}$ Delegated Regulation of the Commission on unmanned aircraft systems and third country operators of unmanned aircraft systems. C(2019) 1821 final.

${ }^{16}$ Point 26, Preamble, Regulation (EU) No. 2018/1139. 
concept is the focus point and that all users of the airspace are under the scope of this regulation. It should be mentioned that the compliance of unmanned aircrafts is regulated by Section 7 of Chapter 3 of the Regulation. This Section is dedicated to UAs and covers their design, production, maintenance and operation. ${ }^{17}$ Article 56 para. 6 provides the possibility of not applying the airworthiness requirements listed in Chapter 4 and 5 of the Regulation for unmanned aircrafts. Instead, EU market harmonisation legislation would apply ${ }^{18}$ for mass-produced drones for mainly recreational use. That is, the UAs whose operation present the lowest risk should not be subject to classic aeronautical compliance procedures (establishing its airworthiness). ${ }^{19}$

Annex IX of the Regulation establishes the essential requirements for unmanned aircrafts, for registration of the devices and their operators and for marking of unmanned aircraft, as well. The operators should be registered if they operate an unmanned aircraft which, in the case of impact, can transfer to a human kinetic energy above 80 Joules or in the case of unmanned aircraft the operation of which presents risks to privacy, protection of personal data, security or the environment etc. ${ }^{20}$ The registration will be done by national aviation authorities, but communication between national registers will be essential. Therefore, in our opinion, the first, i.e. the lowest level of the flexible authorisation system is the duty of registration of UAVs.

The first EU delegated act to which attention must be paid is the Commission's Draft for a delegated regulation on unmanned aircraft systems and thirdcountry operators of unmanned aircraft systems which was adopted by the Commission on $12^{\text {th }}$ March 2019. ${ }^{21}$ This act consists of rules mainly for mass drone production. The detailed rules in Chapter II of this act apply to the drone in the 'open' category as commercial product with the exception of privately built UAs. Two relatively short chapters concern the 'certified' and 'specific' operational categories of UAs and third-country operators.

In order to ensure that the drones placed on the EU market in the open category comply with airworthiness and other technical requirements, first and foremost the manufacturers are obliged to perform a conformity assessment of the product ${ }^{22}$ to establish its conformity with the EU-level harmonised standards. These small drones fall under the scope of EU product safety regulations and therefore the manufacturers must indicate their name, registered trade name or trademark, website address and postal address on the product, or, if it is not possible because

\footnotetext{
${ }^{17}$ With the exception of third country operators' activities in, out or within the territory of EU.

${ }^{18}$ E.g. CE marks.

${ }^{19}$ Commision delegated regulation C (2019) 1821 Final.

${ }^{20}$ Section 4.2. Annex IX.

${ }^{21}$ Commision delegated regulation C(2019) 1821 Final.

${ }^{22}$ Article 13 of Commission Regulation No. C (2019) 1821 Final.
} 
of the small dimensions of the UAs, on the packaging. The manufacturer must draw up an EU declaration of conformity and must affix to the product a CE marking, with the identification number of the notified conformity assessment body, with an UAS class identification label and the indication of the sound power level. ${ }^{23}$

All economic operators who are participating in the supply and distribution chain should cooperate with each other and with the authorities in order to ensure the traceability of the product and to exclude the ones who did make non-compliant UASs available on the market.

Although an exception to the stringent compliance rules is made for the benefit of model aircraft operators, the regulation should also apply to second-hand UASs imported from third countries.

To summarise, the determining factor in the 'open' category is compliance with product safety regulations which ensure that the drone can be operated in a safe manner with no risk to human life or property. The manufacturers are also responsible for making sure their product is not able to be altered or misused for a malevolent purpose. The product safety requirements can substitute the airworthiness requirements on the lowest subcategory of drones.

\section{LIABILITY FOR UTILISATION OF DRONES}

\subsection{Possible injurers and victims, concurrent bases of claims}

First and foremost, it needs to be clarified that the user, the owner himself or a third party may be in the position of the injured person with regard to the damage caused by drone usage. Taking into focus the other side, the persons who are held liable can be the producers on the basis of liability for defective products; the operators, drivers or keepers on the basis of strict liability (see below) or the person who caused the damage by their own conduct on the basis of the general rule of liability for damages. As far as we can see, the EU policymaker prefers product liability in situations when the injured person can claim compensation on more bases of liability.

In the case when the damage is caused by the defective nature of a drone (as product), the provisions of defective product liability are applicable. This strict liability for damages is harmonised EU-wide according to Council Directive No. $85 / 374 / \mathrm{EEC}$ on liability for defective products. In our opinion this strict liability will be applied to drone accidents many times in the future if the causal link between the damage and the defect is proven. According to the report of the Commission on the application of Product Liability Directive, the vehicle is one of the most concerned defective products in the product liability case law between 2000 and

${ }^{23}$ Article 16 of Commission Regulation No. C (2019) 1821 Final. 
2016.. ${ }^{24}$ The aforementioned solution, which substitutes the airworthiness requirements with product safety rules in mass product categories of drones, also serves the goal of liability problems being treated as product liability if possible. The Commission Staff Working Document on the liability for emerging digital technologies ${ }^{25}$ (hereinafter: Working Document) states that product liability and product safety are closely linked and outlines both the existing safety and liability frameworks, which are pillars of the internal market.

The Council Directive imposed on Member States an obligation for exhaustive harmonisation. That is to say, Article 13 of the Directive must be interpreted as meaning that the rights conferred under the legislation of a Member State on the victims of damage caused by a defective product under a general system of liability having the same basis as that put in place by the Directive may be limited or restricted as a result of the Directive's transposition into the domestic law of that State. ${ }^{26}$ It means that within a relationship between producers and customers, the product liability has a priority compared with other national strict liability rules being as bases of the claims for damages, provided that the damage was caused by the defect of the product.

However, the product liability is only one element of the complex system for proper allocation of responsibility. The Working Document continues:

"The EU approach to the internal market is based on common safety rules, underpinned by provisions on product liability, while the regime for contractual or extra-contractual liability for services and the regime for specific contractual or extra-contractual liability for products are left to national law." 27

Taking into account this statement, our opinion is that the EU policymakers do not intend to override national civil liability rules, thus it is still worth examining how the Hungarian judicature can address the liability issues emerging from new technologies, especially from the utilisation of drones. The extra-contractual liability issues will be treated in detail in the following chapter. Nevertheless, it should be highlighted here that the national extra-contractual liability rules (not only fault-based but even strict liability) with their complexity (see below) generally

${ }^{24}$ Section 3, Report from the Commission to the European Parliament, the Council and the European Economic and Social Committee on the Application of the Council Directive on the approximation of the laws, regulations, and administrative provisions of the Member States concerning liability for defective products (85/374/EEC) COM(2018) 246 final.

${ }^{25} \operatorname{COM}(2018) 237$ final.

${ }^{26}$ See EU Case C-183/00 María Victoria González Sánchezvs. Medicina Asturiana SA, Simon Whittaker, (ed.): The development of product liability, Cambridge University Press, 2014, $175-176$.

${ }^{27}$ Working Document COM(2018) 237 final p. 5. 
do not enable victims to obtain compensation because of the burden of proof on victims or evidential difficulties.

"As the accident of the drone may be a result of a rather large set of unknown circumstances, for instance a defect of the device, exceptional weather conditions or other circumstances such as a cyber-attacker, it will be difficult for the victim to prove the elements of a liability claim." 28

Finally, we should mention the fundamental issue that the new Hungarian Civil Code (hereinafter HCC) draws a line between the two regimes of contractual and delictual liability for damages. The HCC excludes parallel compensation claims: "The obligee shall enforce his claim for compensation against the obligor in accordance with the provisions of contractual liability even if the obligor's noncontractual liability also exists." - (i.e. principle of non-cumul). ${ }^{29}$ It is essential to establish whether one of the contracting parties can cause damage to the other party irrespective of their contractual relationship. Furthermore, it is important to identify the legal grounds of claims for damages that are not related to non-performance or performance of a contract.

The judicial practice of rule of non-cumul is taking shape nowadays. Nonetheless, it can be stated that the rule will be interpreted very strictly, that is, the contractual relationship practically excludes the victim's claims on the ground of extra-contractual liability. ${ }^{30}$

\subsection{Drone utilisation as highly dangerous activity}

Although technological development makes everyday life easier, it keeps challenging each member of society to adapt to them.

Fear of an unknown, unassessable or unavoidable risk emerging from activities carried out by others is the key element of the rationale establishing typical strict liability. The negative consequences of non-attributable conduct will be relocated from the victim of damage to another individual and indirectly to the whole society.

${ }^{28}$ Cf. Working Document COM(2018) 237 final p 12.

${ }^{29}$ Para. 6:145 of HCC: The obligee shall enforce his claim for compensation against the obligor in accordance with the provisions on liability for damages for loss caused by non-performance of an obligation even if the obligor's non-contractual liability also exists.

${ }^{30}$ Fazekas Judit showed that the principle of non-cumul could endanger the enforcing of the right to damages based upon the defective product liability. Fazekas Judit, "A kontraktuális és deliktuális felelősség viszonya az új Polgári törvénykönyvben, különös tekintettel a párhuzamos igényérvényesítést kizáró non-cumul szabályra". Állandóság és változás. Tanulmányok a magánjogi felelösség köréből (eds. Ákos Kőhidi, Judit Fazekas, Béla Csitei) Gondolat Kiadó, Budapest, 2017, 24-52. p 29 . 
If the rationales are surveyed which are listed by Géza Marton as theorems of strict liability-beside the principle of prevention (deterrence) - the principle of active interesse (within the same conceptual scope as the principle of cuius commodum eius periculum $)^{31}$ and the principle of societal distribution of damages should also be mentioned. The principle of active interesse has effects upon the rule of deterrence through two channels: At the individual level it heightens liability, but at the societal level it lightens it as a rule of equity. ${ }^{32}$ According to the principle of societal distribution of damages ones can better allocate the losses among the members of the society than the victim could those who shall bear the burden of the risk of damage..$^{33}$

In surveying the development of strict liability rules of national laws for highly dangerous activities, it can be stated that technological changes are accompanied by strict liability. The reasons can be due to the lack of adequate public regulation in the beginning, or imperfection of new technologies. The strict liability approach would acknowledge that the damage resulting from the use of these devices cannot be entirely avoided. ${ }^{34}$

In the future, when the new technology of drones will be part of everyday life and will become a matter of common usage ${ }^{35}$, strict liability may be disengaged. A similar phenomenon was reported by Vivek Sehrawat. In American judicial practice, the assessment of drone use as nuisance is changing. The disturbance caused by drones as a "noise of progress" may be granted better public acceptance in the future. ${ }^{36}$ The stringency of liability will not serve the principle of deterrence anymore. Victim compensation will be more important and it also addresses other instruments such as mandatory liability insurance or social insurance.

At the present, however, policymakers should face emerging technologies as they challenge national liability regulations. In the lack of stringent but acceptable administrative rules for drone utilisation, the deterrence function of liability for

${ }^{31}$ The law may attribute liability to the person that carries out the activity, because this person has created a risk, which materialises in a damage and at the same time also derives an economic benefit from this activity. See Working Document p. 8 (briefly: the one who takes the advantage also shall bear the risk.)

32 Géza Marton: "Veszélyes üzem" I. Polgári Jog 4/1931. 147-161., II, 6/1931 242-255.

33 “...every enterprise has to bear its own costs, damages included, or it has no place under the sun." See Gyula Eörsi, The Validity of Clauses Excluding or Limiting Liability, The American Journal of Comparative Law, 2/1975, 215-235. For the approach of law and economics, see Gerhard Wagner, Robot Liability. Presentation. „Münster Colloquium on EU Law and Digital Economy, Liability for Robotics and the Internet of Things", Mars 2018. (https://papers.ssrn.com/sol3/papers. cfm?abstract_id=3198764, 5 December 2018.)

${ }^{34}$ See Working Document p. 21.

${ }^{35}$ Cf. Principles of European Tort Law. Art. 5:101. (Abnormally dangerous activities) Section (2) An activity is abnormally dangerous if ...[... b) it is not a matter of common usage.

${ }^{36}$ Vivek Sehrawat, Liability Issue of Domestic Drones, Santa Clara High Technology Law Journal 1/2018 110-125. p 126. 
damages becomes more essential. Endre Nizsalovszky, whose words have a particular convincing power, noticed the following while he argued for the strict responsibility of the animal keeper established by the draft Private Law Code of Hungary ${ }^{37}$ in 1928 :

"The individual, as the actual victim, is a member of human society. Therefore, he or she should be ready to suffer encroachments emerging from the human coexistence and they should be prepared for defending against suffering harms. In the determination of the extent or scope of strict liability, the question will gain a special role what extent the individual exposed to damage can be in a position to prevent suffering damage. In this viewpoint the fact is particularly relevant how the dangerous object is bound to place." 38

His opinion is that the damaging effect of railway and road traffic is relatively fixed and that the accidents occur in well-defined places. On the contrary, this feature is lacking in air traffic accidents or damage caused by animals. At this time, drones still do not have full automation; they are not a kind of animal with free will. Their runaway or drifting away are more the direct consequences of lost control on them, but drone operation is a kind of activity in the airspace in which the potential victims have much fewer means to defend against intrusions or damage.

The question is still raised whether the liability for drone utilisation is equivalent to liability for highly dangerous activities. The Hungarian Civil Code applies a blanket clause (Generalklausel) to establish strict liability for highly dangerous activities, leaving undefined which activities are highly dangerous. Thus, the category is unspecified by legislation (with the exemption of special acts e.g. for nuclear power plants and referring rules e.g. keeping dangerous animals or pollution of the environment) but is, however, specified by jurisprudence of the courts (e.g. motor propelled vehicles or machinery, explosive or toxic materials, firearms, etc.).

The dangerousness as a conceptual element hides some inner contradiction, highlighted by Géza Marton. ${ }^{39}$ It is obvious that all liability rules react to some kind of risk of damage. Gyula Eörsi shows that, in conclusion, the liability for damages is also one of the tools for risk management, but with the condition that the damage should have occurred.

37 'Magyarország Magánjogi Törvénykönyve' of 1928

${ }^{38}$ Endre Nizsalovszky, Az objektív felelősség a magánjogi törvénykönyvben Jogállam 4-6/1933, 141-150. pp 147-148.

${ }^{39}$ Marton ibid. 242.-255. If the dangerous activity is carried out with fault, then the liability is based on fault. If the dangerous activity is not unlawful to carry out, then the liability for damages resulting from this activity is not based on fault, because carrying out this permitted activity is not a fault. 
Therefore, the risk of damage, i.e. the dangerousness of an activity, is not a distinguishing factor. ${ }^{40}$ Based on this premise, one can justify that all special liability rules react to some kind of danger. The elaboration of the strict liability rules also shows that. The German liability rule (Gefährdungsprinzip) also means strict liability, or liability without fault.

It is still a challenge to determine the degree of dangerousness (how high or extraordinary it is). As mentioned before, the Hungarian blanket clause provides the opportunity for the judge to form the above-mentioned test (criteria) in order to help determine the appropriate assessment of the case.

Under judicial practice, in order to assess the highly dangerous nature of an activity, one should take into account the characteristic features of the device applied in the course of activity and the potential consequences of the events triggered by this activity. The issue should be assessed on a case-by-case basis whether a slight abnormality occurring under normal conditions of use can cause damage in a disproportionately wide range or disproportionately large amount. ${ }^{41}$

If one examines these criteria in the case of drone usage, it can first be observed that among the land accidents, the physical harmful effect caused during the utilisation of small drones for recreational purposes is relatively small-apart from the buildings and infrastructure requiring special protection. Thus, a small hobby drone is not a source of significant danger. The larger ones, however, especially ones for commercial purposes, can be deemed a device with highly dangerous features such as significant take-off mass and/or kinetic energy, which makes the activity carried out with them highly dangerous, as well.

It can be a question whether future Hungarian judicial practice will take into consideration, for example, the aforementioned EU (draft) rules for drone registrations, that is, whether the lack of the duty of registration does mean that the usage of these smallest drones is not a highly dangerous activity and that the user will be held liable for damages only under the general extra-contractual liability rule (i.e. fault-based rule).

Nevertheless, the obligation of registration is not the only factor which shows how dangerous an activity is. We can mention the example of motor-assisted cycles in Hungarian judicial practice. Although previous academic writing was divided about the issue, the most dominant argument was that despite the lack of registration, mandatory liability insurance and all of the facilitated administrative requirements of utilisation, these vehicles have significant kinetic energy, thus their use is deemed a highly dangerous activity. Nowadays, judicial practice is moving towards establishing strict liability in new cases related to motor-assisted cycles

\footnotetext{
${ }^{40}$ Cf Géza Marton ibid.

${ }^{41}$ BDT 2010. 2358.
} 
and two- or three-wheel motor vehicles. ${ }^{42}$ The effect of compulsory liability insurance can also be observed. As the distinction between the dangerous cars and the slower two- or three-wheeled motor vehicles started to disappear, so does the distinction between airplanes and multicopters.

It should be mentioned here that Péter Miskolczi-Bodnár has an opinion that the analogical application of the model aircraft case ${ }^{43}$ can be an option for drone crash liability issues. ${ }^{44}$

At the end of this Chapter, one more question will be raised in the scope of drone usage. As mentioned before, drones can be equipped at relatively low cost with cameras and other video or voice recorders, which means that the operation of AUSs can infringe on personal rights (privacy, personal data, right of personal portrayal, etc.) as well.

The concept of risk (dangerousness) is determined alongside the statute of liability for highly dangerous activities as a physical risk to which a personal or property right or an interest is exposed. This danger does not have an immaterial meaning. For example, electronic bank account services involve a significant risk of immaterial damage, but the Curia (Supreme Court of Hungary) did not establish strict liability for highly dangerous activities ${ }^{45}$ How the drone usage cases can be assessed when the drone usage does not result in physical harm and damage, but the usage itself does constitute an infringement and may cause significant immaterial damage as it harms privacy. In the case when the nature of the harmful effect is physical, i.e. causes death or personal injuries, it is clear that under HCC provision 2:52 (restitution-grievance award for personal rights' infringement), the provisions of extra-contractual liability for damages are applicable for the claim of restitution, not only the general clause but also the special rules establishing strict liability. ${ }^{46}$

${ }^{42}$ An interesing detail is the judgement of Curia (BH2017.406.) establishing strict liability for damage caused by a kids quad bike and referred the judicial practice about motor-assisted cycles also.

${ }^{43}$ A fatal accident during a model aircraft racing in Hungary in 2006, which kills two human and harms more. Interference in radio signals was the reason why the model PITTS 12S got out of control, cf. judgment No. BDT 2010.2236. Cf. also Final Report of Hungarian Transportation Safety Bureau No. 2006-130-4.

${ }^{44}$ Cf. Péter Miskolczi-Bodnár, „Felelősség az új technológiák alkalmazása során keletkezett károkért”, Technológia jog. Új globális technológiák jogi kihívásai (ed. András Tóth), Károli Gáspár Református Egyetem Állam- és Jogtudományi Kar, Budapest, 2016, p. 211.

45 Judgment of Curia No. Gfv. 30.086/2012/4.

${ }^{46}$ Sec. 2:52 HCC Par. 1 Any person whose rights relating to personality had been violated shall be entitled to restitution for any non-material violation suffered. Par. 2 As regards the conditions for the obligation of payment of restitution - such as the definition of the person liable for the restitution payable and the cases of exemptions - the rules on liability for damages shall apply, with the proviso that apart from the fact of the infringement no other harm has to be verified for entitlement to restitution. Par. 3 The court shall determine the amount of restitution in one sum, taking into account the gravity of the infringement, whether it was committed on one or more 
First, the following issue should be taken into consideration: whether the strict liability rule for highly dangerous activities is overall adequate for any cases and harms to be covered stemming from all types of drone usage. Second, whether it is possible to develop the concept of liability for highly dangerous activities in a direction of response for the significant risk of mass immaterial harms.

\section{CONCLUSIONS}

As taking into consideration the applicability of the liability rule for highly dangerous activities, the first issue is to determine the dangerousness of the drones, precisely of the drone usage. Where the national legal provision (France, Italy, Protugal and the Netherlands) requires the assessment of a movable thing, the issue will be raised about whether the damage is caused by the inherent dangerous nature of the drone or by a defect of the drone. Comparing with the Hungarian solution, the activity, not the movable thing is to be assessed as dangerous.

It should also be mentioned here, however, that at the level of EU harmonisation of liability for damage, the literature predicts no future for the French liability rule for damage caused by things (responsabilité du faire des choses). Gerhard Wagner highlighted that the EU model rules (both the Principles of European Tort Law [PETL] and the Draft of Common Frame of References [DCFR]) rejected the parallel regulation for highly dangerous activities and for keeping a thing and preferred the strict liability of highly dangerous activities ${ }^{47}$ To tell the truth, these model rules however narrow the scope of application only for ultra-hazardous (extraordinary) activity $^{48}$ or for damage caused by motor vehicles in traffic. ${ }^{49}$

Focusing on Hungarian legislation and judicial practice, it can be observed that the recently published judgments hold the operators (owners) liable more and more frequently and for less and less dangerous activity. Following this path, most types of drones and their usage seem to be dangerous "enough" to establish the strict liability of the pilot (e.g. the model aircraft case). Traditionally, the definition of dangerousness reflects the risk of physical harms, not immaterial ones, thus this strict liability rule does not serve well for the compensation of personal injuries.

occasions, the degree of responsibility, the impact of the infringement upon the aggrieved party and his environment.

${ }^{47}$ Gerhard Wagner, „Custodian's Liability in European Private Law”, Handbook of European Private Law Custodian's Liability (eds. Jürgen Basedow, Klaus J. Hopt, Reinhard Zimmermann), (http://ssrn.com/abstract=1766138, 16 January 2019).

${ }^{48}$ PETL art. 5:101.

${ }^{49}$ DCFR art. VI.-3:205. It should be mentioned that the traffic law is also changing because of the appearance of the autonomous cars on the roads. Cf. Ágnes B. Juhász, The Regulatory Framework and Models of Self-Driving Cars, Zbornik radova Pravnog Fakulteta, Novi Sad, 3/2018, 1371-1389. 
The significant risk of infringement of privacy creates a need to establish a rule of strict liability to successfully protect these rights.

The general clause of non-contractual liability under Section 6:519 of $\mathrm{HCC}^{50}$ is grounded on fault. However, the concept of fault (principle of reasonable conduct attributability) in Hungarian law is regulated and interpreted with relatively objective meaning: "Unless otherwise provided for by this Act, in civil law any reference to what can be expected of or by a person, or in a particular situation, is a reference to what can reasonably be expected." "51 The reversal of the burden of proof is also a general feature in the regime of extra-contractual liability. The tortfeasor can exonerate himself if he proves that his conduct was complying with general standard of reasonable conduct. These two characteristics enable the Hungarian tort law to renew itself and adapt to technological and societal challenges and make the general rule for liability relatively objective.

Focusing on the recent tendencies of EU harmonisation, although the liability rule for damage caused by things is not accepted EU-wide, a similarly strict liability rule for drone usage would be a possible way to allocate fairly the damages and react to the above-mentioned risk of immaterial harms of personal rights. As we have experienced, the existing strict liability statute for unlawful data processing, a statute with defences resembling the liability rule for hazardous activities, the new method of data collecting by drone usage will be subject to similar strict liability rules.

\section{REFERENCES}

Adem Ilker, Regulating Commercial Drones: Bridging the Gap between American and Europe Drone Regulations, The Journal of International Business \& Law 15/2016, 313-335.

Ágnes B. Juhász, The Regulatory Framework and Models of Self-Driving Cars, Zbornik radova Pravnog Fakulteta, Novi Sad, 3/2018, 1371-1389.

Endre Nizsalovszky, Az objektív felelösség a magánjogi törvénykönyvben Jogállam 4-6/1933, 141-150. pp 147-148.

Judit Fazekas, "A kontraktuális és deliktuális felelősség viszonya az új Polgári törvénykönyvben, különös tekintettel a párhuzamos igényérvényesítést kizáró non-cumul szabályra". Állandóság és változás. Tanulmányok a magánjogi felelősség köréből (eds. Ákos Kőhidi, Judit Fazekas, Béla Csitei) Gondolat Kiadó, Budapest, 2017, 24-52. p 29.

\footnotetext{
${ }^{50}$ Any person who causes damage to another person wrongfully shall be liable for such damage. The tortfeasor shall be relieved of liability if able to prove that his conduct was not actionable.

${ }^{51}$ The duty of care principle is general in these cases and compares the defendant's behavior, act or omission to what is generally expected from a reasonable person under the given circumstances.
} 
Gerhard Wagner, „Custodian's Liability in European Private Law”, Handbook of European Private Law Custodian's Liability (eds. Jürgen Basedow, Klaus J. Hopt, Reinhard Zimmermann), (http://ssrn.com/abstract=1766138, 16 January 2019).

Gerhard Wagner, Robot Liability. Presentation. "Münster Colloquium on EU Law and Digital Economy, Liability for Robotics and the Internet of Things", Mars 2018. (https://papers.ssrn.com/sol3/papers.cfm?abstract_id=3198764, 5 December 2018.)

Géza Marton: "Veszélyes üzem" I. Polgári Jog 4/1931. 147-161., II, 6/1931 242-255.

Guido Noto La Diega: Machine Rules. Of Drones, Robots, and the Info-Capitalist Society. The Italian Law Journal 2/2016, 367-404.

Gyula Eörsi, The Validity of Clauses Excluding or Limiting Liability, The American Journal of Comparative Law, 2/1975, 215-235.

Kenneth Kuhn, Small Unmanned Aerial System Certification and Traffic Management Systems, RAND corporation, online, 2017 (https://www.rand.org/content/ dam/rand/pubs/perspectives/PE200/PE269/ RAND_PE269.pdf, 12 December 2018.).

Péter Miskolczi-Bodnár, „,Felelősség az új technológiák alkalmazása során keletkezett károkért", Technológia jog. Új globális technológiák jogi kihívásai (ed. András Tóth), Károli Gáspár Református Egyetem Állam- és Jogtudományi Kar, Budapest, 2016, p. 211.

Simon Whittaker, (ed.): The development of product liability, Cambridge University Press, 2014, 175-176.

The Law Library of Congress, Global Legal Research Center, Regulation of Drones. Australia • Canada • China • France • Germany • Israel Japan • New Zealand • Poland $\bullet$ South Africa $\bullet$ Sweden $\bullet$ Ukraine $\bullet$ United Kingdom • European Union (April 2016).

Therese Jones, International Commercial Drone Regulation and Drone Delivery Services, RAND Publications https://www.rand.org/pubs/research reports/RR1718z3.html; (12 December 2017)

Veronika Szikora; Gabor Szilagyi, New Dangerous Practice on the Horizon: Legal Aspects of Drone Usage, 51 Zbornik Radova Pravnog Fakulteta, Novi Sad, 2/2017 499-519.

Vivek Sehrawat, Liability Issue of Domestic Drones, Santa Clara High Technology Law Journal 1/2018 110-125. p 126. 
Др Река М. Пустиахељи, ванредни иррофесор

Универзийей у Мищколиу

Правни факулитети

reka.pusztahelyi@gmail.com

\section{Осврт на грађанскоправну одговорност за штете узроковане беспилотним летелицама}

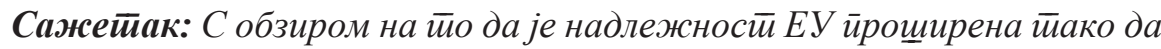

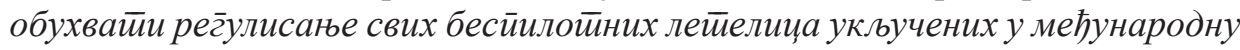
ваздущну йловидбу без обзира на њихове максималне масе за йолейање и у складу са концеййом јединстивеног̄ евройског̄ неба, нова Уредба (ЕУ) 2018 /

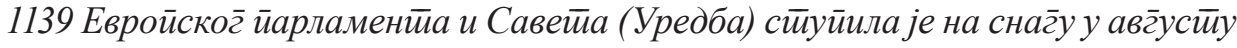
2018. гоодине и односи се на заједничка ирравила у обласиии цивилног̄ ваздухо-

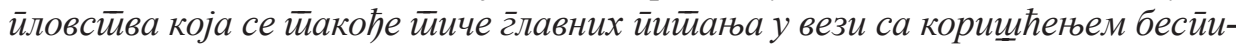

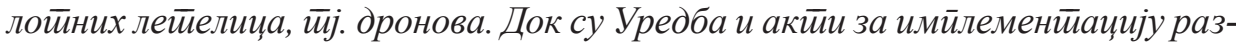

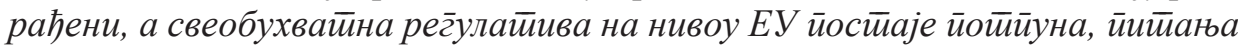
г̄рађанскойравне одг̄оворносиии која се односе на уйойребу дронова изг̄леда да остиају на наиионалном нивоу, с изузетиком Дирекиииве о одг̄оворностии за ироизводе, иодд условом да је узрок несреће која је насйала у вези са дроном био недостиайак ирроизвода.

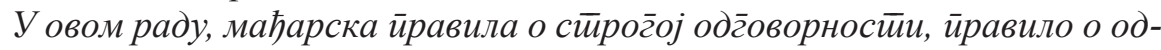

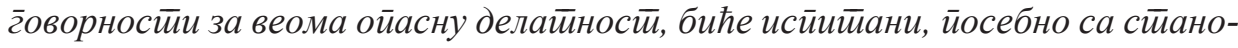
вищйа ойасностии делайностии, са циљем да се одреди начин на који се она може ирименийи на корищћење дрона у будућносиии.

Кључне речи: бесӣилойна летиелииа, ЕУ рег̄улайива, кайег̄оризација

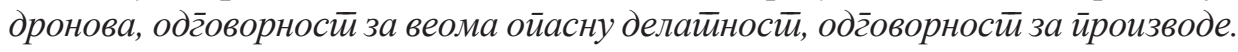

Датум пријема рада: 01.05.2019. 